\title{
Building bridges: African customary family law and children's rights*
}

\author{
by Trynie Boezaart \\ Professor and Head, Private Law, University of Pretoria, South Africa
}

\section{Introduction}

South Africa is a multicultural society where customary law ${ }^{1}$ and common law coexist. ${ }^{2}$ Customary law, being the law of the indigenous African people of South Africa, was the law originally applied in this country and the only legal system other than the common law which is still officially recognised. ${ }^{3}$ (Besides this officially recognised customary law the 'living customary law' also enjoys some standing in post-Apartheid South Africa. ${ }^{4}$ ) There are thus two legal systems that run parallel under the supremacy of the Constitution. ${ }^{5}$ Customary law needs no parliamentary and or other sanction to be (or become) effective. As such it enjoys constitutional sanction. However, the coexistence of two legal systems in one legal order poses challenges. ${ }^{6}$

This paper will focus on the rights of the family, parental responsibilities and rights and children's rights in the context of African customary law. South Africa has gone a long way in safeguarding various rights of children in the Constitution and the principle of the paramountcy of the best interests of the child ${ }^{7}$ is firmly established. ${ }^{8}$ The Constitution, recent legislative measures pertaining to children and judicial precedent have had a

\footnotetext{
* This material is based upon work supported financially by the National Research Foundation. Any opinion, findings and conclusions or recommendations expressed in this material are those of the author and therefore the NRF does not accept any liability in regards thereto.

1 'Customary law' refers to 'the customs and usages traditionally observed among the indigenous African peoples of South Africa and which form part of the culture of those peoples': $s 1$ of the Recognition of Customary Marriages Act 120 of 1998.

${ }^{2}$ Alexkor Ltd and Another $v$ The Richtersveld Community and Others 2004 (5) SA 460 (CC) para 51 at 478; Shilubana and Others v Nwamitwa 2009 (2) SA 66 (CC) para 43; Gumede v The President of the Republic of South Africa 2009 (3) SA 152 (CC) paras 21-22.

${ }^{3}$ GJ van Niekerk 'Legal pluralism' in C Rautenbach, JC Bekker and NMI Goolam (eds) Introduction to Legal Pluralism $3^{\text {rd }}$ ed (2010) 1 at 3. See also Bekker JC Seymour's Customary Law in Southern Africa $5^{\text {th }}$ edition (1989) 11.

${ }^{4}$ In Mabena $v$ Letsoalo 1998 (2) SA 1068 (T) 1074 the court gave effect to living Pedi law that a woman may be the head of a family and receive lobolo. See also Bhe $v$ Magistrate, Khayelitsha, Shibi $v$ Sithole, South African Human Rights Commission v President of the Republic of South Africa 2005 (1) SA 580 (CC) para 87.

${ }^{5}$ Constitution of the Republic of South Africa, 1996 (hereinafter referred to as Constitution), s 8. See s 211(3) that the courts must apply customary law when applicable, subject to the Constitution and any legislation that specifically deals with customary law. See also Mthembu v Letsela 1997 (2) SA 936 (T) at 944B-C.

${ }^{6}$ See Marius Pieterse's 'It's a "Black Thing": Upholding culture and customary law in a society founded on non-racialism' (2001) 17 South African Journal on Human Rights 364 at 393-403 for forceful arguments that legal dualism should make way for harmonization and integration of common law and customary law into one legal system instead. Also note his contention that legal dualism could uphold racialism and thus frustrates a basic constitutional value: $379-389$.

7 'Child' being a person below the age of 18 years, s 17 of the Children's Act 38 of 2005, which repealed the Age of Majority Act 57 of 1972. This provision of the Children's Act became effective on 1 July 2007.

${ }^{8} \mathrm{~S} 28(2)$ of the Constitution.
} 
profound effect on both customary family law and children's rights. The main objective of this paper is to consider the impact of customary family law and practices on children's rights, and vice versa. ${ }^{9}$ This paper will furthermore embark on developing guidelines to balance fundamental rights while protecting the rights of children in Africa.

\section{Cultural values in international law}

An individual's right to participate in cultural practices is the way of expressing a common sense of identity, values and tradition. This right protects the cultural integrity of both the individual and the group. The right of persons to enjoy and maintain their culture is acknowledged by international law, but one should remember that international law is founded mainly on Western systems. The United Nations Convention on the Rights of the Child $(1989)^{10}$ (CRC) has widespread acceptance and even the African Charter on the Rights and Welfare of the Child (1990) ${ }^{11}$ (ACRWC) did not escape its influence. ${ }^{12}$ The ACRWC went a long way to reconcile Western juristic thought and African traditional cultural values. It also provides guidance as to which African cultural practices and traditions are to be abandoned and which should be preserved to effectively protect the rights and welfare of children in Africa. ${ }^{13}$

The CRC obliges state parties to respect the right of the child to preserve his or her identity. ${ }^{14}$ A state party shall also respect the child's right to freedom of thought, conscience and religion, subject to appropriate parental guidance. ${ }^{15}$ State parties are also urged to take effective and appropriate measures to abolish traditional practices which are prejudicial to children's health. ${ }^{16}$

\footnotetext{
${ }^{9}$ Or, worded differently, address the tension between culture and children's rights. See also Thoko Kaime 'The Convention on the Rights of the Child and the cultural legitimacy of children's rights in Africa: Some reflections' (2005) 5 African Human Rights Law Journal 221 at 227; Wieland Lehnert 'The role of the courts in the conflict between African customary law and human rights' (2005) 21 South African Journal on Human Rights 241 at 242.

${ }^{10}$ The most widely ratified (193 of the 195 states) human rights instrument in the world, adopted by the General Assembly of the United Nations on 20 November 1989. South Africa ratified the Convention on 16 June 1995. Hereafter referred to as CRC.

${ }^{11}$ OAU Doc CAB/LEG/24.9/49 (1990) entered into force on 29 November 1999. The OAU was the first regional organisation to adopt a binding treaty specifically focusing on the rights of the child. South Africa ratified the Charter on 7 January 2000. Hereafter referred to as ACRWC.

12 The ACRWC was, according to the Preamble, also inspired by the African Charter on Human and People's Rights (1981), also referred to as the Banjul Charter and the Declaration of the Rights and Welfare of the African Child (1979). In this paper reference will primarily be made to the CRC and the ACRWC being the most important sources of international law on the topic under discussion on the African continent.

${ }^{13}$ Van Bueren International Documents on Children (1998) 33-48; http:www1.umn.edu/humanarts/Africa/afchild.htm last accessed on 18 November 2012.

${ }_{14}$ Art 8(1). See also art 29(1)(c) that state parties agree that education shall be directed to the development of respect for cultural identity and values and art 30(1) that children of indigenous populations shall not be denied the right to enjoy his or her own culture, religion and language. In terms of art 30(2) state parties have to respect and promote the child's right to participate fully in cultural activities.

${ }^{15}$ Art 14.

${ }^{16}$ Art 24(3).
} 
The ACRWC urges states parties in the Preamble to take 'into consideration the virtues of their cultural heritage, historical background and the values of African civilization'. ${ }^{17}$ Article 31(d) obliges children to preserve African cultural values. State parties have to direct the education of children towards preserving and strengthening African morals, traditional values and cultures, ${ }^{18}$ and respect and promote children's participation in cultural activities. ${ }^{19}$ On the other hand the Preamble of the ACRWC also alludes to the negative impact of inter alia culture on the situation of children in Africa. It also provides that 'any custom, tradition, cultural or religious practice' that is inconsistent with the rights, duties and obligations contained in the Charter must be discouraged to the extent that it is inconsistent. ${ }^{20}$ The ACRWC furthermore contains an article dedicated to harmful social and cultural practices and the elimination thereof in specific instances. ${ }^{21}$

From the above it may be said that both these instruments encourage the preservation of tradition and culture. However, the ACRWC is much bolder in both advocating preserving and abolishing the same when it violates children's right to life and health. ${ }^{22}$

\section{Constitutional sanction of cultural values}

The Constitution of the Republic of South Africa, 1996 has played a major role in building bridges and uniting the nation in its diversity. ${ }^{23}$ There is a constitutional obligation on the courts in South Africa to apply customary law when that law is applicable, subject to the Constitution and any legislation that specifically deals with customary law. ${ }^{24}$ Section 39(2) of the Constitution provides that every court, tribunal or forum must develop both common law and customary law to promote the spirit, purpose and objectives of the Bill of Rights. ${ }^{25}$ The Bill of Rights acknowledges all the rights and freedoms conferred on individuals by common law, customary law or legislation, as long as these are consistent with the Bill of Rights. ${ }^{26}$

The Constitution also enshrines the right of persons to enjoy and maintain their culture. ${ }^{27}$ The same can be said about participation in cultural practices. An individual's

17 See Thompson Bankole 'Africa's Charter on Children's Rights: A Normative Break with Cultural Traditionalism' 1992 vol 41 Int \& Comp LQ 432 at 434 that it is a concession to those who argue that the protection of human rights should reflect the spirit of traditional cultural values.

${ }_{10}$ Art 11(2)(c).

${ }^{19}$ Art 12(2).

${ }^{20} \operatorname{Art} 1(3)$.

${ }^{21}$ Art 21.

${ }^{22}$ The CRC merely discourages where the ACRWC abolishes.

${ }^{23}$ See the Preamble of the Constitution: 'united in our diversity'.

${ }^{24}$ S 211(3) of the Constitution; and see Lehnert (2005) 21 South African Journal on Human Rights 243 et seq for a detailed discussion of this subsection of the Constitution. The Namibian Constitution, adopted in 1990 , contains a similar provision in art 66(1).

${ }^{25}$ Own emphasis. See Lehnert (2005) 21 South African Journal on Human Rights 251-253 on the active and passive development of customary law and at 254 on the fact that development of customary law gives due recognition to ss 30,31 and 211(3) of the Constitution.

${ }^{26} \mathrm{~S} 39(3)$. Also see s 39(1) that the values of human dignity, equality and freedom must permeate the interpretation of the Bill of Rights.

${ }^{27}$ Ss 15(3), 30 and 31 of the Constitution. And see s 181(1)(c) of the Constitution on the establishment of the Commission for the Promotion and Protection of the Rights of Cultural, Religious and Linguistic Communities. 
right to participate in cultural practices is the way of expressing a common sense of identity, values and tradition. This right protects the cultural integrity of both the individual and the group. ${ }^{28}$

Constitutional rights, like all other rights, are not without boundaries and conflict between customary law and the Bill of Rights may occur. The limitation clause indicates under what circumstances the rights entrenched in the Bill of Rights may be limited. ${ }^{29}$ Furthermore, rights, even fundamental rights, may be limited in the balancing process when more than one person's rights are competing. The Constitutional Court ruled that there is no hierarchy of constitutional rights. It is a process of weighing up competing interests while also assessing proportionality. ${ }^{30}$

\section{$4 \quad$ Family rights or children's rights}

One of the features of customary law is that groups, rather than individuals, constitute a legal entity. ${ }^{31}$ Marriage in traditional customary law was a matter between two family groups and not merely binding on the parties as individuals. ${ }^{32}$ The focus in customary family law is on the family, and children belong to a family - the father's family. ${ }^{33}$ The best interests of the child are seen as encapsulated in the concept of 'belonging'. ${ }^{34}$ In customary law a member of a family has very few individual rights. ${ }^{35}$ Furthermore, duties are placed on children, ${ }^{36}$ for example to herd cattle and assist with ploughing, in line with a general concept of communities bearing responsibilities. ${ }^{37}$ They are also

${ }^{28}$ See MEC for Education, Kwazulu-Natal v Pillay 2008 (1) SA 474 (CC) 493D.

${ }^{29} \mathrm{~S} 36$ of the Constitution. Also see Lehnert (2005) 21 South African Journal on Human Rights 248.

30 Johncom Media Investments Ltd v M and Others 2009 (4) SA 7 (CC) paras 24 and 19.

31 TW Bennett 'The best interests of the child in an African context' 1999 vol 20 Obiter 145 at 149; JC Bekker and C Rautenbach 'Nature and sphere of application of African customary law in South Africa' in C Rautenbach, JC Bekker and NMI Goolam (eds) Introduction to Legal Pluralism $3^{\text {rd }}$ ed (2010) 15 at 26. See MJ Maluleke 'Culture, tradition, custom law and gender equality' 2012 (15) PER 5/428 who links this with the concept of Ubuntu.

${ }^{32}$ Rwezaura B 'The concept of the child's best interests in the changing economic and social context of sub-Saharan Africa' in Alston P (ed) The Best Interests of the Child - Reconciling Culture and Human Rights (1994) 82 at 88; Olivier et al Indigenous Law (1995) par 10 at p 10 and par 17 at p 17; Ignatius Maithufi 'The best interests of the child and African customary law' in Davel CJ (ed) Introduction to Child Law in South Africa (2000) 137 at 140.

${ }^{33}$ Own emphasis. See Olivier et al Indigenous Law (1995) par 40 at p 39; JC Bekker and GJ van Zyl 'Custody of Black Children on Divorce' 2002 Obiter 116.

${ }^{34}$ Bennett 1999 (20) Obiter 150-151; Nazeem Goolam 'Constitutional Interpretation of the "Best Interests" Principle in South Africa in Relation to Custody' in Eecklaar and Nhlapo 369 at 374; Bekker and Van Zyl 2002 Obiter 117.

${ }^{35}$ Bekker JC Seymour's Customary Law in Southern Africa (1989) 70; Bennett 1999 vol 20 Obiter 146. Also see Goolam in Eecklaar and Nhlapo 374.

${ }^{36}$ Bekker Seymour's Customary Law in Southern Africa (1989) 239. See s 16 of the Children's Act on children's responsibilities.

37 Art 31, which is aligned to the mother document, being the Banjul Charter: Van Bueren 1991 International Children's Rights Monitor 22; Karin CJM Arts 'The international protection of children's rights in Africa: The 1990 OAU Charter on the Rights and Welfare of the Child' 1992 vol 5 African Journal of International \& Comparative Law 139 at 144-145 and 153-154. 
expected to be submissive. ${ }^{38}$ Children's welfare is inseparable from that of their families and therefore they are sometimes expected to make sacrifices for the common good of the family. ${ }^{39}$ The full effect of this statement is borne out by the examples given by Rwezaura, ${ }^{40}$ namely that a daughter may be pledged in marriage to a wealthy husband so that the family can survive a difficult time by obtaining an advance payment of lobolo. ${ }^{41}$ The idea of children enjoying special rights is fundamentally at odds with African legal tradition. ${ }^{42}$ The main concern is to establish to which family a child belongs. The answer hereto is determined by whether lobolo has been paid and that in turn will depend on whether the mother is married or not. ${ }^{43}$ Lobolo is a crucial factor, because it inter alia signifies the transfer of the woman's childbearing capacity to her husband and his family. ${ }^{44}$

Western legal systems are individualised and lean towards nuclear families. The Preamble of the CRC makes is clear that states parties to this particular convention are convinced that the family is the fundamental group of society. ${ }^{45}$ It also recognises that children should grow up in a family to develop their full potential. The fact that parents jointly are regarded as the primary care-givers of children can be deduced from many of its articles. ${ }^{46}$ The ACRWC also recognises that children should grow up in a family environment ${ }^{47}$, that the family is the natural unit and basis of society ${ }^{48}$ and parents are the primary care-givers. ${ }^{49}$ In South Africa the Constitution affords families limited protection, but the Children's Act acknowledges the role of the family explicitly. ${ }^{50}$

The CRC and the ACRWC are not ad idem when submission or obedience to parental supervision is concerned. In the language of the CRC parental supervision entails

${ }^{38}$ See Bennett Customary Law in South Africa 329-331 on 'Powers of discipline' and JC Bekker 'Interaction between Constitutional Reform and Family Law' 1991 Acta Juridica 1 at 3 on the respect of children for the father bordering on fear.

39 TW Bennett Customary Law in South Africa (2004) 295.

40 Rwezaura in Alston (ed) The Best Interests of the Child - Reconciling Culture and Human Rights (1994) at 90- 91. See also Bekker JC Seymour's Customary Law in Southern Africa (1989) 57.

${ }^{41}$ The definition in s 1 of the Recognition of Customary Marriages Act 120 of 1998: "property in cash or in kind, whether known as lobolo, bogadi, bohali, xuma, lumalo, thaka, ikhasi, magadi, emabheka or by any other name, which a prospective husband or the head of his family undertakes to give to the head of the prospective wife's family in consideration of a customary marriage'. See also Olivier et al Indigenous Law (1995) par 29 at p 24 and note that the authors opine that the English translation 'dowry' is a misnomer.

42 Bennett 1999 (20) Obiter 146, 147 and 150; Bennett Customary Law in South Africa 296; Bekker and Van Zyl 2002 Obiter 117.

${ }^{43}$ Bennett 1999 (20) Obiter 146; Bennett Customary Law in South Africa 307.

44 Olivier et al Indigenous Law (1995) par 35 at p 33; Bennett Customary Law in South Africa 309; Maithufi in Davel (ed) Introduction to Child Law in South Africa 143. Lobolo thus also serves to legalise the marriage and legitimate the children born of that woman.

${ }^{45}$ See also International Covenant on Civil and Political Rights, art 23(1) (1966), 999 U.N.T.S. 171, reprinted in 6 I.L.M. 368 (1967); International Covenant on Economic, Social and Cultural Rights, art 10(1), 993 U.N.T.S. 3, reprinted in 6 I.L.M. 360 (1967).

${ }^{46}$ See arts 5, 7(1), 9(1), 9(3), 10(1), 14(2), 18(1), 18(3), 24(2)(e), 27(2) and 29(1)(c). See also Kaime (2005) 5 African Human Rights Law Journal 226.

${ }^{47}$ Preamble. See also art 11(4) and $14(2)(f)$.

${ }^{48}$ Art 18(1). See also Kaime (2005) 5 African Human Rights Law Journal 226.

${ }^{49}$ Art 20(1) and 19(1). See also arts 19(2), 19(4) and 20(2).

${ }^{50} \mathrm{~S}$ 106(1)(f) and (k). 
directing and guiding a child in a manner consistent with the evolving capacities of the child. ${ }^{51}$ In terms of the ACRWC children bear the responsibility to respect their parents, superiors and elders at all times. ${ }^{52}$ The parents have a duty to ensure that domestic discipline is administered humanely and consistent with the child's dignity. ${ }^{53}$ This implies that parents have a right to discipline a child and that discipline includes corporal punishment. Unfortunately both customary law and common law are at odds with the higher standard prevailing under the CRC in this regard. To this date parents may discipline their children and discipline may include corporal punishment as long as it is reasonable chastisement. ${ }^{54}$

International law obliges state parties to adhere to the best interests standard when children are involved. Article 3(1) of the $\mathrm{CRC}^{55}$ describes the best interests of the child as a primary consideration. ${ }^{56}$ The ACRWC phrases it in even stronger terms in Article $4(1)$ because it is not merely termed as a primary consideration, but the primary consideration. ${ }^{57}$

The question, what exactly a child's best interests are, is a factual one that has to be determined according to the circumstances of each individual case ${ }^{58}$ The best interests

${ }^{51}$ Art 5. See Johan D van der Vyver 'Children's Rights, Family Values, and Federal Constraints' vol 15 no 1 (Spring 2012) Journal of Markets and Morality 117 at 121 on perceptions in the USA that the CRC reduces the role of parents to that of giving advice instead of instruction.

${ }^{52}$ Art 31(a). See Van Bueren who rightfully objects that this responsibility is too unquestioning and general: 'A new children's treaty' 1991 vol 8 International Children's Rights Monitor 20 at 22. Also see art 9(2) on parental guidance and direction in the exercise of the child's right to freedom of thought, conscience and religion.

${ }_{54}$ Art 20(1)(c).

${ }^{54}$ The South African Law Commission, as it then was, recommended that parents' right to reasonable chastisement should no longer be a defence to a charge of assault in order to protect children from serious infringement upon their physical integrity: Review of the Child Care Act Project 110 para 10.2.11. This recommendation was formulated in clause 139(3) of the Children's Amendment Bill but unfortunately this specific section never found its way into the Children's Act 38 of 2005.

${ }^{55}$ See Philip Alston 'The Best Interests Principle: Towards a Reconciliation of Culture and Human Rights' Ph Alston (ed) The Best Interests of the Child - Reconciling Culture and Human Rights (1994) 1 et seq on the best interests principle as articulated in art 1(1) of the CRC and in general, Hamilton 'Implementing children's rights in a transitional society' in Davel (ed) Children's Rights in a Transitional Society (1999) 13 at 19.

${ }^{56}$ Also see the United Nations Convention on the Elimination of All Forms of Discrimination Against Women(1979) (CEDAW) art 5(b) and art 16(1)(d) which uses the term 'paramount' instead of 'primary'. This document was ratified by South Africa in December 1995.

${ }^{57}$ Van Bueren 1991 International Children's Rights Monitor 21. See Davel 'The African Charter on the Rights and Welfare of the Child, family law and children's rights' 2002 De Jure 281 at 283 on the fact that the Charter increases the level of protection for children when compared to the CRC in a number of important respects.

${ }_{58}$ Van Oudenhove v Gruber 1981 (4) SA 857 (A) 868C; Godbeer v Godbeer 2000 (3) SA 976 (W) 981; Bernard Bekink \& Mildred Bekink 'Defining the Standard of the Best Interest of the Child: Modern South African Perspectives' (2004) 1 De Jure 21 40. J Heaton 'An individualised, contextualised and childcentred determination of the child's best interests, and the implications of such an approach in the South African context' 2009: 34(2) Journal for Juridical Science 1 at 9 aptly explains this child-centred individualised approach as follows: 'Every body or person who has to determine the child's best interests must evaluate each individual case or situation in light of the individual child's position and the effect that the individual child's circumstances are having or will probably have on the child.' She also pleads for a 
standard has been criticised as being vague and indeterminate. ${ }^{59}$ On the other hand it gives courts discretion to apply different cultural norms. ${ }^{60}$ This inherent flexibility to contextualise the best interests standard should be seen as a strength. ${ }^{61}$

The South African Constitution raised this standard to a principle of paramountcy which is also echoed in the Children's Act. ${ }^{62}$ The legislation adopted in the post-constitutional South Africa is child-centred ${ }^{63}$ and individualised. ${ }^{64}$ However, the Constitutional Court has made it very clear that in spite of the paramountcy of the child's best interests, other constitutional rights may not be trumped or ignored. ${ }^{65}$ It is therefore inevitable that children's rights will sometimes be limited.

\section{$5 \quad$ Parental responsibilities and rights}

In several African countries the legal systems (both general and customary) still make a distinction between children born in and out of wedlock. ${ }^{66}$ Needless to say, the latter suffer both a serious social stigma and legal disabilities particularly in the context of inheritance rights. ${ }^{67}$ Under the general law several legislative measures have levelled

balanced approach to be adopted when incorporating cultural and religious rules and practices in determining the child's best interests: 12. See Bhe and Others v Magistrate, Khayalitsa, and Others (Commission for Gender Equality as Amicus Curiae); Shibi $v$ Sithole and Others; South African Human Rights Commission and Another v President of the Republic of South Africa and Another 2005 (1) SA 580 (CC) paras 234 and 235; MEC for Education: KwaZulu-Natal v Pillay 2008 (1) SA 474 (CC); AD and Another v DW and Others (Centre for Child Law Amicus Curiae; Department for Social Development as Intervening Party) 2008 (3) SA 183 (CC) para 50.

${ }_{59}$ S v M (Centre for Child Law as Amicus Curiae) 2008 (3) SA 232 (CC) para 23. See R Mnookin 'Child Custody Adjudication: Judicial Functions in the Face of Indeterminacy' (1975) 3 Law and Contemporary Problems 226 260; Jacqueline Heaton 'Some General Remarks on the Concept "Best Interests of the Child"' (1990) 53 THRHR 95; Clark 2000 Stellenbosch Law Review 15. S Parker 'The Best Interests of the Child-Principles and Problems' in Alston (ed) The Best Interests of the Child-Reconciling Culture and Human Rights (1994) 2629 explores the indeterminacy and focuses on the role localised conventions on values play in providing a degree of predictable application. Also see Bennett 1999 (20) Obiter 155.

${ }^{60}$ See eg Alston (1994) 8 International Journal of Law and the Family 1; B Rwezaura 'The Concept of the Child's Best Interests in the Changing Economic and Social Context of Sub-Sahara Africa' (1994) 8 International Journal of Law and the Family 82; Heaton 2009: 34(2) Journal for Juridical Science 8-9.

${ }^{61}$ S v M (Centre for Child Law as Amicus Curiae) 2008 (3) SA 232 (CC) para 24; Bennett Customary Law in South Africa 296.

${ }^{62}$ See s 9.

${ }^{63}$ See $\mathrm{s} 6$ of the Children's Act 38 of 2005 which establishes a child-centred approach in respect of all legislation, proceedings and state measures regarding children.

${ }^{64}$ S v M (Centre for Child Law as Amicus Curiae) 2008 (3) SA 232 (CC) para 24; Heaton 2009: 34(2) Journal for Juridical Science 5-6.

${ }^{65}$ Minister of Welfare and Population Development v Fitzpatrick and Others 2000 (3) SA 422 (CC) para 20; Sonderup v Tondelli and Another 2001 (1) SA 1171 (CC) para 29; De Reuck v Director of Public Prosecutions (Witwatersrand Local Division) and Others 2004 (1) SA 406 (CC) para 55 (obiter); S v M (Centre for Child Law as Amicus Curiae) 2008 (3) SA 232 (CC) paras 25, 26 and 42.

${ }^{66}$ Arts 1992 African Journal of Int \& Comp L 158. See also Thompson 1992 Int \& Comp LQ 442. But then the term 'illegitimate' must be interpreted in terms of the usual rule of customary law where all children born of a wife in a customary marriage belonged to the husband, even if the children were conceived out of wedlock: Olivier NJJ, Bekker JC, Olivier NJJ (Jnr) and Olivier WH Indigenous Law (1995) par 7 at p 6.

${ }^{67}$ Mthembu v Letsela 1997 (2) SA 936 (T) 686F, which was decided before the Children's Act under the Interim Constitution 200 of 1993, bears witness to the discrimination that children born out of wedlock suffered with regards to succession rights. Sadly, the judgement was confirmed by the Supreme Court of 
the playing field regarding discrimination based on birth out of wedlock ${ }^{68}$ and the Children's Act finally did away with the classification of children based on their parents' marital status. In terms of this Act the distinction is now between parents. They are either married or unmarried.

It is interesting to note that shared responsibilities are not unfamiliar to customary law. However, in customary family law it was shared by the family group concerned. In common law, after the Children's Act became operative, parental responsibilities and rights are shared by parents in the first instance, ${ }^{69}$ with the possibility that it can be shared on a broader basis including inter alia members of the extended family as well.

\subsection{Parental responsibilities and rights of unmarried mothers}

If a child's mother is unmarried in customary law, parental rights vest in the father of the mother or his heir. ${ }^{70}$ Strictly speaking, the mother did not obtain parental responsibilities and rights in customary law. Bennett ${ }^{71}$ makes the very valid point referring to the nondiscrimination section ${ }^{12}$ that this rule of customary law is open for constitutional challenge and should be declared invalid. ${ }^{73}$

The acquisition of parental responsibilities and rights by mothers is now regulated under the Children's Act. In terms of section 19 of the Act the mother of a child (whether married or unmarried) has full parental responsibilities and rights in respect of the child. ${ }^{74}$ Only when the biological mother of a child is an unmarried child and the biological father of the child does not have guardianship in respect of the child, the guardian of the child's biological mother is the guardian of the child. ${ }^{75}$

\subsection{Parental responsibilities and rights of unmarried fathers}

In customary law, an unmarried father does not have automatic parental responsibilities and rights. As a general principle, he may acquire such by marrying the child's mother.

Appeal (Mthembu $v$ Letsela [2000] 3 All SA 219 (SCA)) without reference to the best interests of the child standard or the non-discrimination principle both clearly provided for in international law (art 3 of the ACRWC) and the Interim Constitution. See Zondi v President of the Republic of South Africa 2000 (2) SA $49(\mathrm{~N})$ where the court ordered that regulations (reg 2 of the Regulations for the Administration and Distribution of the Estates of Deceased Blacks GN R200 of 1987) which provided that an estate had to devolve according to customary law should be struck down to confer on all children, also those born out of wedlock, the same succession rights. The court ordered that the intestate estate had to devolve in accordance with the Intestate Succession Act 89 of 1987. Also see Maithufi in Davel (ed) Introduction to Child Law in South Africa 147. Unfortunately the same development did not occur in all African countries. See Fitzgerald and another $v$ Chong and others [2012] JOL 29591 (ZH) for the position in Zimbabwe.

${ }^{68} \mathrm{~S}$ 1(2) of the Intestate Succession Act 81 of 1987; s 2D(1)(b) of the Wills Act as amended by s 4 of the Law of Succession Amendment Act 43 of 1992.

${ }^{69}$ Ss 18 and 30 of the Children's Act, which is aligned with art 18(1) of the CRC. See art 19 of the ACRWC.

${ }^{70}$ Olivier et al Indigenous Law (1995) par 146 at p 155; Bennett Customary Law in South Africa 308; Maithufi in Davel (ed) Introduction to Child Law in South Africa 145; Bekker and Van Zyl 2002 Obiter 117.

${ }^{71}$ Bennett Customary Law in South Africa 313.

${ }^{72} \mathrm{~S} 9$.

${ }^{73}$ Referring to Fraser v Children's Court, Pretoria North 1997 (2) SA 261 (CC).

${ }^{74} \mathrm{~S} 19(1)$.

${ }^{75} \mathrm{~S}$ 19(2). 
In some systems of customary law, such as the Swazi and Pondo, payment of seduction damages will give him parental responsibilities and rights. For Zulu and Tswana people additional considerations will be necessary (isondlo in Zulu and dikotlo in Tswana). ${ }^{76}$

It is interesting to note that the best interests of the child standard played some part in the decision whether the unmarried father obtained parental responsibilities and rights before the implementation of the Children's Act. This is why transactions that smacked of child trafficking or an ulterior motive, simply to lay hands on a daughter's lobolo, were not enforced. ${ }^{77}$ In Hlope $v$ Mahlalela ${ }^{78}$ the court refused, albeit obiter, to allow the natural father to acquire rights to his child by tendering the outstanding balance of the lobolo. Today, under the Children's Act and to the dismay of some ${ }^{79}$ the best interests standard is not employed in the acquisition of an unmarried father's parental responsibilities and rights. The best interests standard on the other hand plays a pivotal role in the exercise of parental responsibilities and rights.

Section 21 of the Children's Act now contains the parental responsibilities and rights of unmarried fathers. An unmarried father acquires full parental responsibilities and rights in respect of the child in terms of section 21(1) -

(a) if at the time of the child's birth he is living with the mother in a permanent lifepartnership; or

(b) if he, regardless of whether he has lived or is living with the mother-

(i) consents to be identified or successfully applies to be identified as the child's father or pays damages in terms of customary law;

(ii) contributes or has attempted in good faith to contribute to the child's upbringing for a reasonable period; and

(iii) contributes or has attempted in good faith to contribute towards expenses in connection with the maintenance of the child for a reasonable period.

There is some acknowledgement of customary law in section 21 of the Children's Act. The 'damages in terms of customary law' that section 21(1)(b)(i) refers to is the payment of a vimba (or nquthu) beast as an admission of paternity. ${ }^{80}$ The same can be said about assuming responsibility for maintenance and lying-in expenses. Isondlo have been interpreted by the courts as a type of maintenance. ${ }^{81}$ According to Seymour's Customary Law in Southern Africa it has a broader meaning, signifying the bringing up or maintaining of a child. ${ }^{82}$

\footnotetext{
${ }^{76}$ Bennett Customary Law in South Africa 310.

${ }^{77}$ Bennett 1999 (20) Obiter 147 and 148; Bennett Customary Law in South Africa 311; Maithufi in Davel (ed) Introduction to Child Law in South Africa 144.

781998 (1) SA 449 (T) 459.

${ }^{79}$ Bonthuys E 'Parental Rights and Responsibilities in the Children's Bill 70D of 2003' 2006 Stellenbosch Law Review 482 at 487.

${ }^{80}$ Bennett Customary Law in South Africa 314.

${ }^{81}$ Hlengwa v Maphumulo 1972 BAC 58 (NE); Bennett Customary Law in South Africa 312.

82 Bekker JC Seymour's Customary Law in Southern Africa (1989) 242. Isondlo, usually one beast per child, is claimed by a family head from the person who asserts parental responsibilities and rights towards a child whom the family head has brought up or maintained.
} 


\subsection{Parental consent for a child's marriage}

Parental consent for marriage is required if the child is a minor. In traditional customary law the father's consent was sufficient. ${ }^{83} \mathrm{~A}$ father's disapproval of the marriage could be used to prove that the two contracting family groups had not reached agreement. ${ }^{84}$ Although it was traditionally not possible for a mother to be her daughter's guardian, it was found in Mabena $v$ Letsoalo ${ }^{85}$ that there had been instances where the mother negotiated and received the lobolo. The court recognised this principle of 'observed' customary law because it constituted development in line with the spirit, purpose and objectives of the (interim) Constitution and found that the mother was entitled to consent to the marriage. Now the Recognition of Customary Marriages Act 120 of 1998 requires ${ }^{86}$ that if either of the spouses is a minor, both the parents or guardians of that spouse have to consent to the child's marriage. If parental consent cannot be obtained, the presiding officer of the Children's Court ${ }^{87}$ may grant consent. ${ }^{88}$ If any one of the parents or the presiding officer of the Children's Court refuses consent, the minor has to approach the High Court for permission. ${ }^{89}$

Parental consent is not the only requirement for a customary marriage. The Minister of Home Affairs, or any officer authorised by the Minister in writing, has to grant permission in writing for the child to conclude a customary marriage. ${ }^{90}$ The Minister (or the said authorised official) will only grant permission if the marriage is desirable and in the interests of the parties concerned. The Minister's permission does not exempt the parties from any other legal requirements. ${ }^{91}$ There is no direct authority on the consequences of the marriage if the Minister's consent has not been obtained. Van Schalkwyk puts forward a very valid argument that nullity will ensue under these circumstances. ${ }^{92}$ If this permission of the Minister was not obtained but the marriage was concluded according to the Act in all other respects, he or she has a discretion to declare the marriage to be a valid customary marriage if he or she considers the marriage to be desirable and in the interests of the parties. ${ }^{93}$ If a customary marriage is concluded without either parental consent, the Commissioner's consent or the court's

\footnotetext{
83 Olivier et al Indigenous Law (1995) par 34 at p 31; R-M Jansen 'Customary family law' in C Rautenbach, JC Bekker and NMI Goolam (eds) Introduction to Legal Pluralism $3^{\text {rd }}$ ed (2010) 45 at 51.

84 Jansen in Rautenbach, Bekker and Goolam (eds) Introduction to Legal Pluralism 51.

851998 (2) SA 1068 (T) 1073-1074.

${ }^{86} \mathrm{~S} 3(3)(a)$. Like s 24A(1) of the Marriage Act 25 of 1961 regarding civil marriages. See also s 18(3)(c)(i) of the Children's Act 38 of 2005. See L Neil van Schalkwyk 'Kommentaar op die Wet op Erkenning van Gebruiklike Huwelike 120 van 1998' 2000 (63) Journal of Contemporary Roman-Dutch Law 479 at 483 that the consent in terms of the Recognition of Customary Marriages Act need not be in writing. However, in terms of the Children's Act the consent has to be in writing.

${ }_{87}$ Previously referred to as a Commissioner of Child Welfare.

${ }^{88}$ Marriage Act 25 of 1961 , s 25(1).

${ }^{89} \mathrm{~S} 25(4)$.

${ }^{90} \mathrm{~S} 3(4)(a)$ of the Recognition of Customary Marriages Act.

${ }^{91}$ S 3(4)(b) of the Recognition of Customary Marriages Act.

${ }^{92}$ See Van Schalkwyk 2000 Journal of Contemporary Roman-Dutch Law 485. He does so because this is the way in which the courts interpreted the civil marriage equivalent, namely s 26(1) of the Marriages Act 25 of 1961: Shields $v$ Shields 1959 (4) SA 16 (W) 22D-E and 23A; Abels v Abels 19612 SA 639 (C) 638639.

${ }^{93} \mathrm{~S} 3(4)(\mathrm{c})$.
} 
permission, the marriage is voidable and an application for annulment may be brought by the parent, guardian or the child. ${ }^{94}$

\subsection{Parental responsibilities upon divorce}

In customary law, the father had 'absolute' rights regarding the guardianship and 'custody' of the children upon divorce. ${ }^{95}$ The children belonged to the father's family group. The court as upper guardian of children has long before the advent of the Constitution or the Recognition of Customary Marriages Act modified customary law in this respect, emphasising that the best interests of children are decisive. ${ }^{96}$

Then came the constitutional dispensation, and Hlope $v$ Mahlalela ${ }^{97}$ confirms the fact that there will be no turning back on this issue: The applicant claimed custody of his child, who had been living with her maternal grandparents for three years after the mother's death. The applicant and the deceased were married by civil rites. The marriage was however preceded by a lobolo contract. The respondents, the grandparents, averred that, as the applicant has not fully discharged his lobolo obligations, he was not entitled to custody of the child. The applicant, on the other hand, relied on the rule of customary law which entailed that the father always has custody of his child, irrespective of whether the lobolo has been paid in full or not at all.

The court did not hesitate to apply the best interests of the child standard in deciding this dispute. ${ }^{98}$ The court held that whatever the position had been in customary law regarding the custody of children, the basic principles thereof had been excluded in favour of common law. ${ }^{99}$ Therefore, irrespective of whether or not the parents are

\footnotetext{
${ }^{94}$ S 24A of the Marriage Act. See also s 24(1) of the Marriage Act 25 of 1961 that applies to customary marriages in terms of $s$ 8(4)(a) of the Recognition of Customary Marriages Act. With regard to the patrimonial consequences of the 'marriage', the court may make any order with regard to the division of the spouses' matrimonial property that it deems just.

95 Bekker JC Seymour's Customary Law in Southern Africa (1989) 227; Olivier et al Indigenous Law (1995) par 65 at p 83; Maithufi in Davel (ed) Introduction to Child Law in South Africa 143; Jan C Bekker, Gerhard J van Zyl, Erika Wakeford and Johan MT Labuschagne 'Legal remedies available to an aggrieved parent: Observations on the Parental Alienation Syndrome in custody and access litigation' 2004 vol 5 no 1 Child Abuse Research in South Africa 26 at 31; Jansen in Rautenbach, Bekker and Goolam (eds) Introduction to Legal Pluralism 66.

${ }_{96}$ Mabuza v Nhlapo 1980 AC (N-E) 144; Motloung v Motaung 1980 NAC (N-E) 159; Hlophe v Mahlalela 1998 (1) SA 449 (T); Bekker Seymour's Customary Law in Southern Africa (1989) 217 and 227, mentioning specific but very familiar examples such as that a mother be awarded custody of very young children or when the father has ill-treated or neglected the children etc; Olivier et al Indigenous Law (1995) par 65 at p 83; Maithufi in Davel (ed) Introduction to Child Law in South Africa 143; Rwezaura in Alston (ed) The Best Interests of the Child - Reconciling Culture and Human Rights (1994) 105-110.

971998 (1) SA 449 (T). See also Knoetze 'Custody of a black child' 1999 Obiter 207 at 207-208 and Maithufi in Davel (ed) Introduction to Child Law in South Africa 146.

${ }_{98}$ The court applied s 30(3) of the interim Constitution, 1993: 459E. S 28(2) of the Constitution played its part in the cases decided after 1994.

${ }^{99}$ 458F-G.
} 
unmarried or lobolo has been paid in full, the best interests standard applies to all children, including custody disputes in customary law. ${ }^{100}$

The Recognition of Customary Marriages Act equates the position of spouses upon the dissolution of a customary marriage with a divorce. ${ }^{101}$ It is interesting to note that the ACRWC does exactly the same: State parties must ensure equality of rights and responsibilities during marriage and in the event of dissolution. ${ }^{102}$ It is also noteworthy that section 8(5) of the Recognition of Customary Marriages Act provides that in mediating any dispute or matter that arose prior to the dissolution of a customary marriage by a court, nothing in section 8 may be construed to limit the role of any person recognised by customary law, including any traditional leader in the mediation process. Mediation also plays a prominent role in the Children's Act. ${ }^{103}$ Section 8(4)(e) obliges the court to take any arrangement or provision that has been made for maintenance in accordance with customary law into consideration when making an order with regard to maintenance. ${ }^{104}$ The payment of lobolo and isondlo will thus be factors that will be considered. ${ }^{105}$

Bekker and Boonzaaier expressed the view in 2007 that section 28(2) of the Constitution is the benchmark in dealing with guardianship and 'custody' decisions when Africans are involved. ${ }^{106}$ They were pessimistic about the application of the paramountcy of the best interests of the child standard as they perceived it to be 'notoriously vague'. They correctly submitted that in establishing the best interests of African children, African culture and belief systems should be considered. They then state that '[s]ection 28(2) in given circumstances be modified by cultural factors peculiar to South Africa'. ${ }^{107}$ The opposite, that section 28(2) 'modified' cultural practices and customary law, is perhaps a better reflection of the reality.

\section{$6 \quad$ Child marriages}

Child betrothals are not allowed in customary law and void ab initio. ${ }^{108}$ In many African cultures child marriages occur. ${ }^{109}$ Procreation is viewed as the main purpose of

\footnotetext{
100 459D. The court carefully examined all the evidence and reached the conclusion that it was in the child's best interests to award custody to the father and reasonable access to the maternal grandparents: 462A-D.

${ }^{101}$ S 8(3). It provides that both the Mediation in Certain Divorce Matters Act 24 of 1987 and s 6 of the Divorce Act 70 of 1979 apply to the dissolution of a customary marriage. See also $s$ 8(4)(a) that incorporates inter alia s 8 of the Divorce Act.

${ }^{102}$ Art 18(2). And in the case of dissolution, 'provision shall be made for the necessary protection of the child'.

${ }^{103} \mathrm{~S} 6(4)(a), 21(3)(a), 33(5)(b)$, etc.

104 See also art 18(3) of the ACRWC that '[n]o child shall be deprived of maintenance by reference to the parents' marital status'.

${ }^{105}$ Isondlo is an animal or limited amount that a father pays to somebody else that raised his child. See further Bennett Customary Law in South Africa 282-284.

106 'How equal is equal? A legal-anthropological note on the status of African women in South Africa' 2007

(2) De Jure 277 at 287.

107 Own emphasis.

108 Bekker JC Seymour's Customary Law in Southern Africa (1989) 99; Olivier et al Indigenous Law (1995) par 11 at p 11; Jansen in Rautenbach, Bekker and Goolam (eds) Introduction to Legal Pluralism 48.
} 
heterosexual relationships in traditional societies and therefore puberty is regarded as the marriageable age. ${ }^{110}$ The ACRWC expressly proscribes both child betrothals and child marriages. ${ }^{111}$ It is the first binding human rights instrument that sets eighteen as the minimum age of marriage and prohibits child betrothals and marriage. ${ }^{112}$ The same article obliges state parties to take effective action, including legislation, specifying that the minimum age of marriage is eighteen years. ${ }^{113}$ In this instance common law seems further away from the international benchmark set in the ACRWC than current customary law in terms of the Recognition of Customary Marriages Act 120 of 1998. Section 3(1) of the Act requires prospective spouses to a customary marriage to be above the age of eighteen years. Section 4 provides the Minister or delegated official with the discretion to grant written permission to children to marry if the Minister (or official) considers such marriage desirable and in the interests of the parties concerned. Regrettably, in terms of the common law, puberty is still the marriageable age. ${ }^{114}$

\section{$7 \quad$ Abduction of the bride (ukuthwala)}

The ukuthwala custom entails that a suitor (and/or his friends) remove a girl from her family home, 'abduct' his bride (ukuthwala), and bring her to his family to enter into marriage negotiations. Normally the man or his family takes the initiative in approaching the family of the girl with a view to negotiate and formalise a marriage. ${ }^{115}$ The ukuthwala custom is widely practiced in rural areas but especially prevalent in the Nguni-group, among the Xhosa. ${ }^{116}$

Three forms of ukuthwala can be distinguished depending on who initiates the process: ukuthwala okungena vumelano (or ukugcagca) is when the groom and bride-to-be reached decision beforehand and the bride-to-be 'elopes' to the young man's family

\footnotetext{
${ }^{109}$ For a global effort to end child marriages see 'Africa: Girls Not Brides - A New Global Partnership to End Child Marriage' Press release 20 September 2011, The Elders (London) available at allAfrica.com. It was reported in the Legalbrief of 26 September 2012 that the government of Nigeria announced its intention to enforce the Child Protection and Welfare Act by prosecuting men who marry under-age girls: 'Child marriages finally outlawed in Nigeria'. The new law also penalizes parents and guardians who collude with men to arrange a child marriage. Offenders face prison terms of up to 20 years.

110 Thompson 1992 vol 41 Int \& Comp LQ 432 at 439-440.

111 Art 21(2). See Van Bueren 1991 International Children's Rights Monitor 20.

112 Danwood Mzikenge Chirwa 'The merits and demerits of the African Charter on the Rights and Welfare of the Child' 2002 vol 10 The International Journal of Children's Rights 157 at 167.

${ }^{113}$ Art 21(2) also requires state parties to 'make registration of all marriages in an official registry compulsory'. The strong stance of the ACRWC urged Thompson 1992 Int \& Comp LQ 438 to aver that the Charter departs significantly from African cultural traditionalism.

${ }^{114}$ See s 26(1) of the Marriage Act 25 of 1961 which requires the Minister's consent for girls under 15 and boys under 18. It can be stated that the differing age restrictions set for girls and boys in s 26(1) amounts to gender discrimination and therefore in contravention of $s 9$ of the Constitution of the Republic of South Africa, 1996: Van der Vyver in Robinson (ed) The Law of Children and Young People in South Africa (1997) 265 at 292 and 294.

${ }^{15}$ Bekker JC Seymour's Customary Law in Southern Africa (1989) 98; Olivier et al Indigenous Law (1995) par 10 at p 10. Otherwise her guardian or his messenger will follow her up and take her back: Bekker JC Seymour's Customary Law in Southern Africa (1989) 98.

${ }^{116}$ Olivier et al Indigenous Law (1995) par 10 at p 9; Jansen in Rautenbach, Bekker and Goolam (eds) Introduction to Legal Pluralism 47.
} 
home so that marriage negotiations can commence. ${ }^{117}$ The 'abduction' then takes place with the girl's consent while she might even fake resistance. It would be a disgrace if the girl goes willingly. ${ }^{118}$ The second form of ukuthwala, known as ukuthwala kobulawa, is when the two family groups reach agreement without consulting the girl or bride-tobe. ${ }^{119}$ This form of ukuthwala will inevitably sometimes be against her will. The third form of ukuthwala is when neither the girl nor her family has prior knowledge of the 'abduction'. ${ }^{120}$

Unfortunately this custom is so acceptable and many aware of the fact that the 'abduction' takes place for good reason, that onlookers will not interfere even if the girl is screaming and crying. ${ }^{121}$ According to custom she will be treated with utmost kindness. ${ }^{122}$ The essence of this custom is the formation of a marriage which explains why the 'abduction' can be performed by somebody else for and on behalf of the groom. ${ }^{123}$ This could also mean that the bride has to wait at the grooms' family home and wait on his arrival (or return from work elsewhere). ${ }^{124}$ In other instances the 'abduction' is arranged with the girl's guardian himself. ${ }^{125}$

The suitor, a relative or the friend that conducted the thwala has to report back to the girl's home that she is safe. This is when the negotiations regarding the cattle that has to be paid for the girl starts and the relationship between the families is established. The girl is then released to go to her father's home and later returns 'in grand style' and accompanied by the bridal party. ${ }^{126}$

Ukuthwala gives rise to delictual liability only in some communities. ${ }^{127}$ In other communities, it will constitute a delict only under certain circumstances, for instance if thwala takes place without a marriage proposal, it is an insult for both the bride and her father which would entitle them to claim a fine, a thwala or bopha beast. ${ }^{128}$ The bopha beast is also payable if the suitor's family does not have the required lobolo or if the

117 Olivier et al Indigenous Law (1995) par 10 at p 9-10. Amongst the Swazi it is called ukutiba because the girl absconds to the young man's kraal: she 'steals herself'.

${ }^{118}$ Mkupeni v Nomungunya 1936 NAC (C\&O) 77 Tabankulu (Pondo); Bekker JC Seymour's Customary Law in Southern Africa (1989) 98; DS Koyana and JC Bekker 'The indomitable ukuthwala custom' 2007 (1) De Jure 139 at 140.

${ }_{119}$ Olivier et al Indigenous Law (1995) par 10 at $\mathrm{p} 9$.

120 Olivier et al Indigenous Law (1995) par 10 at p 10.

${ }^{121}$ Koyana and Bekker 2007 De Jure 139.

122 Jansen in Rautenbach, Bekker and Goolam (eds) Introduction to Legal Pluralism 47.

${ }^{123}$ Koyana and Bekker 2007 De Jure 141.

${ }^{124}$ Mkokobane $v$ Mngqumazi 1947 NAC (C\&O) 41.

${ }^{125}$ Dyongo v Nani 2 NAC 102 (1911), where her brother was her guardian; Koyana and Bekker 2007 De Jure 141.

${ }_{127}^{126}$ Koyana and Bekker 2007 De Jure 141.

127 Labuschagne and Schoeman 'Die inheemse ukuthwala-gebruik, wederregtelikheidsbewussyn en strafregtelike aanspreeklikheid weens ontvoering' 1988 TRW 33-45; Olivier et al Indigenous Law (1995) par 119 at p 123; Bekker 'Law of delict' in Joubert, Faris and Church (eds) LAWSA vol 32 (2009) paras 180-181.

${ }^{128}$ Bekker JC Seymour's Customary Law in Southern Africa (1989) 98. See Olivier et al Indigenous Law (1995) par 10 at p 9 who distinguish between the inkomo yokuthwala, being the beast paid as damages, the inkomo yokkhona, payable for defloration and the inkomo yesisu for the pregnancy. 
girl's father refuses permission. ${ }^{129}$ The bopha beast is payable to the father or guardian of the girl. It is also contrary to customary law for the suitor to have intercourse with the 'abducted' girl and such conduct will make him liable for seduction over and above the lobolo that has to be paid if the marriage takes place or the thwala or bopha beast if the marriage does not take place. ${ }^{130}$

The custom of ukuthwala must clearly be distinguished from the common law crime of abduction. ${ }^{131}$ Abduction entails the unlawful removal of a child, a girl or a boy, from parental care with the purpose of having intercourse with the child. ${ }^{132}$ On the other hand only girls are taken away in the custom, usually with her and or her parent's consent and without the intension of seducing her. ${ }^{133}$

The ukuthwala custom does not amount to a forced marriage. In terms of section 3(1)(a) of the Recognition of Customary Marriages Act the consent of both prospective spouses is required to conclude a valid customary marriage. Koyana and Bekker contend that the ukuthwala custom is gaining ground and has a rightful place as a peculiar type of elopement. ${ }^{134}$ They argue that the custom should be upheld for rural people living under customary law. ${ }^{135}$

Unfortunately press reports have drawn attention to the fact that offences are committed against girls under the pretence of the ukuthwala custom. Maluleke avers that ukuthwala nowadays involves the kidnapping, rape and forced marriage of girls by much older men. ${ }^{136}$ In both international law ${ }^{137}$ and common law the state bears the

${ }^{129}$ Olivier et al Indigenous Law (1995) par 119 at p 123.

${ }^{130}$ Bekker JC Seymour's Customary Law in Southern Africa (1989) 98; Koyana and Bekker 2007 De Jure 141-142.

${ }^{131}$ Olivier et al Indigenous Law (1995) par 119 at p 123 and par 126 at 131.

132 S v Killian 1977 (2) SA 31 (C); S v L 1981 (1) SA 499 (BSC) 502. Other crimes that could also be committed are: sexual activities with children, grooming and rape in terms of ss 15 to 18 of the Criminal Law (Sexual Offences and Related Matters) Amendment Act 32 of 2007. S 17 deals with parents and relatives who collude in and /or assist with the sexual acts. See also s 71 of the same Act where they can be charged with trafficking in persons.

${ }^{133}$ Koyana and Bekker 2007 De Jure 142.

${ }^{134} 2007$ De Jure 143-144.

1352007 De Jure 144.

1362012 PER / PELJ 11/428. See also Lea Mwambene and Julia Sloth-Nielsen 'Benign accommodation? Ukuthwala, "forced marriage" and the South African Children's Act' vol 2.1 Spring 2011 Journal of Family Law and Practice 5.

${ }^{137}$ Art 19(1) of the CRC. Also see art 34 that state parties are obliged to protect children from all forms of sexual exploitation (or other exploitation in terms of art 36) and abuse. Also see art 6 on the right to life. Regarding the ACRWC, see art 16 on the protection of children against physical violence, art 21 on the protection of children against harmful social and cultural practices and art 5 on the right to life, survival and protection. 
responsibility to protect the child from violence, injury and abuse. ${ }^{138}$ Accordingly this matter is under investigation. ${ }^{139}$

\section{$8 \quad$ Other cultural practices ${ }^{140}$}

Virginity testing is sometimes conducted and the outcome affects the girls' status in marriage contracts (lobolo). ${ }^{141}$ In some communities a special 'virginity' beast is payable (to the girl's mother) when a virgin gets married or is seduced. ${ }^{142}$ It is known as the ngquthu or umqhoyiso beast.

Male circumcision ${ }^{143}$ is said to be the focal event of initiation and in those cultures that require it, considered as an indispensable transition to adulthood. ${ }^{144}$ The process entails the removal of the foreskin, preferably with a spear, being a traditional weapon. ${ }^{145}$ The leaves of a medicinal plant are used as a wound dressing. Ischaemia, sepsis, gangrene and transfer of sexually transmitted diseases occur mainly due to the fact that the procedure is not performed by health professionals, not under sterile circumstances and often using one spear for more than one boy at a time. Inevitably, every year the media reports on mutilations, amputations and mortality among male initiates. ${ }^{146}$

Female genital mutilation (FGM) comprises all procedures involving "partial or total removal of the external genitalia or other injury to the female genital organs for nonmedical reasons'. ${ }^{147}$ Infection, keloid scar formation, HIV transmission, reproductive health complications, tetanus, bleeding, persistent menstrual pain, painful intercourse and tearing during child delivery are some of the consequences. ${ }^{148}$

${ }^{138}$ Ss 11 and 28(1) of the Constitution and also ss 10 and 12. See also s 12(1) and specifically s 12(2) of the Children's Act 38 of 2005. Also see I Currie and J de Waal The Bill of Rights Handbook (2005) 290. See also Mwambene and Sloth-Nielsen vol 2.1 Spring 2011 Journal of Family Law and Practice 5 at 8-10 on ukuthwala and the right to equality.

${ }^{139}$ A media statement was issued by the Secretary of the South African Law Reform Commission on 7 December 2010: 'Government mandates the South African Law Reform Commission to investigate the practice of ukuthwala'.

${ }^{140} \mathrm{~A}$ few of the most important other traditional practices are mentioned, without exploring any of them in depth. Each of these practices has been dealt with in research already, but an overview is important before suggesting functionally and culturally relevant guidelines for protecting the rights and welfare of children in Africa.

${ }_{141}$ Bennett Customary Law in South Africa 303-304.

142 Olivier et al Indigenous Law (1995) par 50 at p 57.

${ }^{143}$ See Julia Sloth-Nielsen 'A foreskin too far? Religious, "medical" and customary circumcision and the Children's Act 38 of 2005 in the context of HIV/Aids' vol 16 (2012) Law Democracy \& Development 69-88 available at http://dx.doi.org/10.4314/ldd.v16i1.4 last accessed on 4 January 2013.

${ }^{144}$ TW Bennett Customary Law in South Africa (2004) 302.

${ }^{145}$ Rienie Venter 'Xhosa male initiation: an evaluation of children's human rights' 2011 12(2) Child Abuse Research: A South African Journal 87 at 89 and 91.

146 'Circumcision: 230 dead' Pretoria News 1 August 2011 at 2; Venter 2011 12(2) Child Abuse Research: A South African Journal 87.

${ }^{147}$ World Health Organization An Update on WHO's Work on female genital mutilation (FGM) Progress Report (2011) 1.

${ }_{148}$ The Centre for Gender and Social Policy Studies, Obafemi Awolowo University, Ile-Ife, Nigeria. Consultant: Dr RO Soetan Report submitted to the African Institute for Economic Development and Planning (IDEP), Dakar, Senegal, October 2001 at 24; Berhane Ras-Work 'The impact of harmful traditional practices on the girl child' EGM/DVGC/2006/EP.4 1-13 at 4. 
The international standard enunciated in the CRC in terms of article 24(3) provides the following -

States Parties shall take all effective and appropriate measures with a view to abolishing traditional practices prejudicial to the health of children. ${ }^{149}$

Article 16 of the CRC could also be important. It prohibits any arbitrary or unlawful interference with a child's privacy and provides every child with a right to protection against such interference or attacks. ${ }^{150}$

The protection in terms of the ACRWC is phrased much stronger: A whole article is dedicated to 'Harmful social and cultural practices': Article 21(1) provides that:

States Parties to the present Charter shall take all appropriate measures to eliminate harmful social and cultural practices affecting the welfare, dignity, normal growth and development of the child and in particular:

(a) those customs and practices prejudicial to the health or life of the child; and

(b) those customs and practices discriminatory to the child on the grounds of sex or other status. ${ }^{151}$

Although virginity testing might not be prejudicial to a child's life or health and thus not covered under article 24(3) of the CRC it is hard to believe that it can be conducted without some invasion of the child's privacy and thus in contravention of article 16(1) of the CRC. Both male and female circumcisions are, or depending on the circumstances under which it is performed, can be prejudicial and therefore covered under article 24(3). ${ }^{152}$ But the protection under the ACRWC is much stronger because all these cultural practices are most definitely discriminatory on the basis of gender and therefore a harmful social and/or cultural practice that has to be abolished in terms of art 21(1). ${ }^{153}$

\footnotetext{
${ }^{149}$ The CRC has been criticised for not giving children enough protection against harmful traditional practices: Benyam D Memzur 'The African Children's Charter versus the UN Convention on the Rights of the Child: A zero-sum game?' (2008) 23 SAPR/PL 1 at 5.

${ }^{150}$ See also art 24(1) on the child's right to the highest attainable standard of health.

151 Art 21(1)(a) and (b). See also art 27(1)(a) regarding sexual exploitation and art 29(a) regarding abduction of children. Art 1 puts a rather weak obligation on state parties to discourage any custom, tradition or cultural practice which is inconsistent with the rights, duties and obligations contained in the Charter: Arts 1992 African Journal of International and Comparative Law 150.

${ }^{152}$ When children's lives are at stake, art 6 of the CRC recognises the inherent right to life of every child and state parties have to ensure 'to a maximum extent possible' the survival and development of the child. See also art 2(2). Art 5(1) of the ACRWC that every child 'has an inherent right to life'. State parties have to 'ensure, to their maximum extent possible, the survival, protection and development' of a child: art 5(2). See also art 14(1) that every child has the right to enjoy the 'best attainable' state of health; that measures have to be taken to reduce child mortality art 14(2)(a) and that the state has to provide medical assistance to all children art 14(2)(b).

${ }^{153}$ See also Memzur (2008) 23 SAPR/PL 12 and 18. The principle of non-discrimination is embodied in art 3 of the ACRWC and note that it is again mentioned in art 21(1)(b). See also art 7 of the ACRWC on the freedom of expression.
} 
The international and regional treaties mandate state parties to take legislative action to ensure that harmful cultural and traditional practices are eliminated.

The Children's Act 38 of 2005 contains a separate section on social, cultural and religious practices. ${ }^{154}$ Section 12 provides the following:

(1) Every child has the right not to be subjected to social, cultural and religious practices which are detrimental to his or her well-being.

(2) A child-

(a) below the minimum age set by law for a valid marriage may not be given out in marriage or engagement; and

(b) above that minimum age may not be given out in marriage or engagement without his or her consent.

(3) Genital mutilation or the circumcision of female children is prohibited.

(4) Virginity testing of children under the age of 16 is prohibited.

(5) Virginity testing of children older than 16 may only be performed-

(a) if the child has given consent to the testing in the prescribed manner;

(b) after proper counselling of the child; and

(c) in the manner prescribed.

(6) The results of a virginity test may not be disclosed without the consent of the child.

(7) The body of a child who has undergone virginity testing may not be marked.

(8) Circumcision of male children under the age of 16 is prohibited, except when-

(a) circumcision is performed for religious purposes in accordance with the practices of the religion concerned and in the manner prescribed; or

(b) circumcision is performed for medical reasons on the recommendation of a medical practitioner.

(9) Circumcision of male children older than 16 may only be performed-

(a) if the child has given consent to the circumcision in the prescribed manner;

(b) after proper counselling of the child; and

(c) in the manner prescribed.

(10) Taking into consideration the child's age, maturity and stage of development, every male child has the right to refuse circumcision.

Section 12 thus gives effect to article 21 of the ACRWC and addresses the concerns of the Committee on the Rights of the Child in this regard. ${ }^{155}$ The Children's Act obliges care-givers to safeguard children's health and protect them from maltreatment and abuse. ${ }^{156}$ It is a criminal offence to neglect or abuse a child. ${ }^{157}$ Children that are

\footnotetext{
${ }^{154}$ See also Ronaldha Ngidi 'Upholding the best interests of the child in South African customary law' in Trynie Boezaart Child Law in South Africa (2009) 225 at 236-240; and Daksha Kassan and Prinslean Mahery 'Special child protective measures in the Children's Act' in Trynie Boezaart Child Law in South Africa (2009) 185 at 188-194.

${ }^{155}$ Concluding Observations of the Committee on the Rights of the Child: South Africa CRC/C/15/Add.122 (2000) para 10. There are also various provincial enactments on circumcision, such as Northern Province Circumcision Schools Act 6 of 1996, Application of Health Standards in Traditional Circumcision Act 6 of 2001 of the Eastern Cape, the Free State Initiation School Health Act 1 of 2004. On the interplay between the provincial laws and the Children's Act, see Sloth-Nielsen vol 16 (2012) Law Democracy \& Development 82

${ }^{156}$ S 32 of the Children's Act.

${ }^{157}$ S 305 of the Children's Act.
} 
exposed to circumstances that may seriously harm them or are maltreated or abused fit the definition of a 'child in need of care' and should be dealt with in terms of section 150 of the Children's Act.

It has been convincingly argued ${ }^{158}$ that the practice of circumcision of girls is covered by the obligation on state parties to eliminate it in international law. ${ }^{159}$ At national level South Africa followed suit and prohibited (and criminalised ${ }^{160}$ ) the practice. ${ }^{161}$ In the case of male circumcision and virginity testing, regulation is preferred above abolishing the custom. ${ }^{162}$

It is also very important that the child's own view is regarded when children partake in cultural practices such as these. There is a firm international law standard to adhere to in this regard, ${ }^{163}$ which has been duly incorporated into domestic law in South Africa. ${ }^{164}$

\section{$9 \quad$ The way forward}

The question has been asked whether South Africa is developing customary law in line with international human rights standards and the Constitution or whether we are 'killing it softly'. In my opinion there is a third option that has to be put forward: It is all about a problem of contemporary universal significance, namely children's rights. We are developing and protecting children's rights because that is where the future lies. What needs to be preserved and what needs to be abandoned in African culture and tradition should be answered in the first instance with reference to the advancement of children's rights. Functionally and culturally relevant guidelines need to be developed to effectively protect the rights and welfare of children in Africa.

The first guideline should be to uphold international human rights or rather children's rights standards. Note that the ACRWC stands firm that it is children's rights first and then custom, tradition and cultural practices. ${ }^{165}$ The same has been said about the

\footnotetext{
${ }^{158}$ Arts 1992 African Journal of International and Comparative Law 151.

${ }^{159}$ Art 24(3) of the CRC and the ever stricter obligation in art 21(1) of the ACRWC.

${ }_{160}^{160}$ S 305(1)(a) of the Children's Act.

${ }^{161} \mathrm{~S}$ 12(3) of the Children's Act. The same has been done in various other African countries such as Kenya (Children Act (Cap. 586) 2001 (Kenya) s 14), Ghana (Children Act 1998 s 13) and Tanzania (The Law of the Child Act 2009 (Tanzania) s 13(1)). On a recent proclamation in Eritrea, see Memzur (2008) 23 SAPR/PL 19. It was reported in Legalbrief Today on 5 May 2010 that lawmakers from 27 African countries gathered in Dakar on 3 May 2010 for a two-day conference to push for a UN ban on FGM as a breach of human rights.

162 The so-called balanced approach: Kassan and Mahery in Boezaart Child Law in South Africa 193, but contravening s 12 results in criminal offences: s 305(1)(a) of the Children's Act.

${ }^{163}$ Art 12 of the CRC and art 4(2) of the ACRWC. See Memzur (2008) 23 SAPR/PL 9 that art 12(1) offers a wider principle that all children capable of 'forming' their views have to be able to participate while art 4(2) takes the restrictive approach that children capable of 'communicating' their own views must participate. Also see Chuma Himonga 'The right of the child to participate in decision making: A perspective from Zambia' in Ncube W (ed) Law, Culture, Tradition and Children's Rights in Eastern and Southern Africa (1998)95 at 98-99 on art 12 of the CRC.

${ }^{164} \mathrm{Eg}$ ss 12(5)(a), 12(9)(a) and 10 of the Children's Act 38 of 2005 and Regulation 5 Form 1 (Consent to a virginity test by a child) and Form 2 (Consent to Social or Cultural Circumcision) of the Regulations Social Development) in terms of the Children's Act.

${ }^{165}$ Art 1(3) of the ACRWC and see Chirwa 2002 vol 10 The International Journal of Children's Rights 158.
} 
CRC. ${ }^{166}$ The approach in international law is to favour those cultural practices which advance the promotion of children's rights and override those which are considered damaging to the protection of children's rights. ${ }^{167}$ The South African Constitution invites all courts to prefer an interpretation that is consistent with international law over any alternative interpretation that is not. ${ }^{168}$ The constitutional court also ruled that international law includes binding as well as non-binding law. ${ }^{169}$

The second guideline is upholding the child's best interests. The best interests standard is one of the basic principles in international law pertaining to children. Decisions taken in respect of children must be directed at the enhancement of their growth and development. The South African Constitution, renowned for its stance on children's rights, elevated the standard to a principle of paramountcy. In some instances it might amount to developing or modifying customary law, but it could also amount to developing common law. A recent case, Maneli $v$ Maneli ${ }^{170}$ provides proof that we do not modify section 28(2) of the Constitution or 'kill' the customary law 'softly': The applicant and the respondent were married in 1992 after having first concluded a customary marriage. In 1997 they lawfully adopted an orphaned child in terms of Xhosa customary law ${ }^{171}$ while not complying with the legislation pertaining to adoptions in South Africa. ${ }^{172}$ The parties separated in 2004 following a breakdown of the marriage and the child remained in the care of the applicant. Although the respondent maintained the child and took care of her educational and medical needs while the parties lived together, he argued after the separation that he is no longer obliged to do so. His argument is based on the fact that he is neither the biological father nor legally adopted the child in terms of the Children's Act 38 of 2005 or its predecessor. ${ }^{173}$ The court thus had to decide whether the respondent is legally obliged to maintain the child as envisaged in terms of section 10 of the Maintenance Act 99 of $1998 .{ }^{174}$

The court made it clear that the development of both customary law and common law have to be consonant with promoting the best interests of the child as envisaged in the constitutional prescript on the paramountcy of the child's best interests. ${ }^{175}$ Judge Mokgoatheng stated that the Constitution does not renounce the existence of any rights

\footnotetext{
${ }^{166}$ By Kaime (2005) 5 African Human Rights Law Journal 227.

${ }^{167}$ Kaime (2005) 5 African Human Rights Law Journal 228.

${ }^{168} \mathrm{~S}$ 233. The Constitution enjoins the courts, tribunals and forums to consider international law when interpreting the Bill of Rights: $s$ 39(1)(b). See also s 231(4) that international agreements have to be enacted into law by national legislation.

169 S v Makwanyane 1995 (3) SA 391 (CC) 413.

1702010 (7) BCLR 703 (GSJ).

${ }^{171}$ Customary law adoptions are widely practiced by Xhosas in the Eastern and Western Cape provinces of South Africa. It entails the performance of Xhosa traditional rites and rituals to proclaim publicly that the adoptive parents have formally accepted parental responsibility for the child. Thereafter the child is regarded as a child of the adoptive parents: Maneli v Maneli 2010 (7) BCLR 703 (GSJ) paras 4 and 5 at 705.

${ }^{172}$ At that stage Chapter 4 of the Child Care Act 74 of 1983, which is now replaced by Chapter 15 of the Children's Act 38 of 2005.

${ }_{173}$ Para 8.

${ }_{174}$ Para 9.

${ }^{175}$ Paras 24, 39 and 44.
} 
conferred by the common law or the customary law, as long as it is consistent with the Constitution. ${ }^{176}$ He found that neither the Child Care Act nor the Children's Act repealed or modified the Xhosa customary law of adoption, and that the common law had to be developed to accommodate customary adoptions. ${ }^{177}$ The development of the common law will improve the effectiveness of the maintenance system for a major group in society. ${ }^{178}$ Before reaching the conclusion that the respondent has a legal duty to maintain the child adopted in terms of customary law, judge Mokgoatheng expressed the following strong sentiments regarding upholding cultural institutions: ${ }^{179}$

Children develop fully only under the protective umbrella of their culture of origin. For the minor child's dignity, sense of identity and psychological well-being, it is preferable if it [sic] grows up in the social milieu from which it originates.

Thirdly, child participation is obligatory and the child's voice must be heard in all cultural practices in which they partake. Although children did not have any special rights in customary law, custom gave them opportunities to express their needs and opinions, (not through a Legal Aid appointed curator or representative) but through ritualised songs, dances and plays. ${ }^{180}$ They also had recognised channels in the family through which they expressed their needs, like grandparents, father's aunt or mother's brother. ${ }^{181}$ But a radically changing or changed social order, urbanisation, labour migration, poverty, disintegration of the extended family network and disease took its toll. Self-sufficient individualism has emerged. In some instances these changes brought about a situation where decision-making takes place in a smaller group with more opportunity for a child to express his or her view freely. ${ }^{182}$ Unfortunately, this is not always the case. ${ }^{183}$ Cultural practices which prevent the child from expressing his or her views or which do not give due weight to the views of the child must be considered as inconsistent with the rights of the child and at least revisited. ${ }^{184}$ In Kotze $v$ Kotze ${ }^{185}$ the court declined a parent's imposition of religious dogma upon a child. Likewise cultural practices should not be imposed on a child. The child has to participate freely in the decision-making process.

\footnotetext{
${ }^{176}$ Para 29.

${ }^{177}$ He obiter stated that these acts must be interpreted purposively not to exclude adoption by customary law: para 23.

${ }_{178}^{178}$ Para 40.

179 Para 43.

${ }^{180}$ Bennett 1999 (20) Obiter 151; Himonga in Ncube W (ed) Law, Culture, Tradition and Children's Rights in Eastern and Southern Africa (1998)103-104.

${ }^{181}$ Bennett 1999 (20) Obiter 151; Himonga in Ncube W (ed) Law, Culture, Tradition and Children's Rights in Eastern and Southern Africa (1998)104-106.

182 Himonga in Ncube W (ed) Law, Culture, Tradition and Children's Rights in Eastern and Southern Africa (1998)107

${ }^{183}$ See Himonga in Ncube W (ed) Law, Culture, Tradition and Children's Rights in Eastern and Southern Africa (1998)108-111 for many examples.

${ }^{184}$ Kaime (2005) 5 African Human Rights Law Journal 231. See also UN General Assembly 'Promotion and protection of the rights of children' Report of the Third Committee A/67/453 (December 2012) Chapter III on 'The rights of indigenous children' para 42(f).

${ }^{185} 2003$ (3) SA 628 (T) at 629, per Fabricius AJ.
} 
Fourthly, the role of the judiciary should not be underestimated in balancing the right to culture or customary law and any other constitutionally protected right. The judiciary is a central medium for giving effect to human rights and therefore children's rights in any democracy. A sensitive approach towards customary law does justice to the constitutional recognition of customary law. ${ }^{186}$ The right to practice cultural practices has to be balanced against non-discrimination, equality and human dignity when practices such as virginity testing and female genital mutilation are considered. ${ }^{187}$

Fifthly, the fundamental principles underlying the Bill of Rights are crucial, such as the principle of equality and the principle of tolerance and accommodation. ${ }^{188}$ These values or principles should guide the interpretation of inter alia the best interests standard towards a multicultural approach. ${ }^{189}$

Finally, it should also be acknowledged that internal and properly structured discourse directed at the re-evaluation, reformulation and replacement of values while upholding African cultural integrity will build the bridge between principle and reality and enhance children's rights. ${ }^{190}$

${ }^{186}$ Lehnert (2005) 21 South African Journal on Human Rights 265 and 267.

187 See also Victoria Bronstein 'Reconceptualizing the customary law debate in South Africa' (1998) 14 South African Journal on Human Rights 388 at 389 and 410.

${ }^{188}$ Rylands v Edros 1997 (1) BCLR 77 (C) 90. See also Pieterse (2001) 17 South African Journal on Human Rights 403 arguing for sensitive, informed and context-based accommodation of cultural principles and values in both legislation and judicial decision-making.

189 Nazeem Goolam 'Constitutional Interpretation of the "Best Interests" Principle in South Africa in Relation to Custody' in Eeckelaar and Nhlapo 369 at 371.

${ }^{190}$ See also Kaime (2005) 5 African Human Rights Law Journal 237. 